\title{
Agreeing on global research priorities for medication safety: an international prioritisation exercise
}

\author{
Aziz Sheikh¹, Igor Rudan ${ }^{1}$, \\ Kathrin Cresswell ${ }^{1}$, Neelam \\ Dhingra-Kumar ${ }^{2}$, Mei Lee \\ Tan², Minna L Häkkinen², \\ Liam Donaldson ${ }^{2,3}$; on \\ behalf of the World Health \\ Organization's Management \\ Team on Research Priorities \\ for Medication Safety
${ }^{1}$ Usher Institute of Population Health Sciences and Informatics, University of Edinburgh, Edinburgh, UK
${ }^{2}$ World Health Organization, Geneva, Switzerland
${ }^{3}$ London School of Hygiene and Tropical Medicine, London, UK

\section{Correspondence to:}

Prof. Aziz Sheikh

Chair of Primary Care Research and Development

Usher Institute of Population Health

Sciences and Informatics

College of Medicine and Veterinary

Medicine

University of Edinburgh

Old Medical School

Teviot Place

Edinburgh EH8 9AG, UK

aziz.sheikh@ed.ac.uk

\begin{abstract}
Objectives Medication errors continue to contribute substantially to global morbidity and mortality. In the context of the recent launch of the World Health Organization's (WHO) Third Global Patient Safety Challenge: Medication Without Harm, we sought to establish agreement on research priorities for medication safety.
\end{abstract}

Methods We undertook a consensus prioritisation exercise using an approach developed by the Child Health and Nutrition Research Initiative. Based on a combination of productivity and citations, we identified leading researchers in patient and medication safety and invited them to participate. We also extended the invitation to a further pool of experts from the WHO Global Patient Safety Network. All experts independently generated research ideas, which they then independently scored based on the criteria of: answerability, effectiveness, innovativeness, implementation, burden reduction and equity. An overall Research Priority Score and Average Expert Agreement were calculated for each research question.

Findings 131 experts submitted 333 research ideas, and 42 experts then scored the proposed research questions. The top prioritised research areas were: (1) deploying and scaling technology to enhance medication safety; (2) developing guidelines and standard operating procedures for high-risk patients, medications and contexts; (3) score-based approaches to predicting high-risk patients and situations; (4) interventions to increase patient medication literacy; (5) focused training courses for health professionals; and (6) universally applicable pictograms to avoid medication-related harm. Whilst there was a focus on promoting patient education and involvement across resource settings, priorities identified in high-resource settings centred on the optimisation of existing systems through technology. In low- and middle-resource settings, priorities focused on identifying systemic issues contributing to high-risk situations.

Conclusions WHO now plans to work with global, regional and national research funding agencies to catalyse the investment needed to enable teams to pursue these research priorities in medication safety across high-, middleand low-resource country settings.

Medication errors are common and are responsible for considerable - potentially avoidable - morbidity and mortality [1]. They are also costly for patients, health systems and society; globally medication errors impose an estimated financial burden of US $\$ 42$ billion per year, accounting for almost 1\% of total expenditure on health worldwide [2]. 
Most studies of the frequency and nature of medication error have come from high-resource country settings. These have found that around 2-3\% of clinical encounters in primary care settings and $10 \%$ involving hospital in-patients will result in errors [3-10]. Not all will be clinically important, but medication errors have been found to be the commonest resulting in harm [11]. Research in low-resource health care settings suggests a broadly comparable frequency of medication-related harm [6-12]. This body of work is challenging to interpret, because of the heterogeneity in the definitions used, patient populations studied and methodologies employed. Despite these challenges, the over-riding message from this body of evidence is very clear: medication errors affect patients of all ages, both sexes, occur globally across all health care settings, and, most importantly, they are largely preventable.

The World Health Organization (WHO) established two previous Global Patient Safety Challenges. Each Challenge sought to highlight a major patient safety problem impacting all countries and health systems. The first of these, Clean Care is Safer Care (2005) focused on reducing health care-associated infections and the second [13], Safe Surgery Saves Lives (2007), aimed to improve the safety of surgical processes [14]. Building on the success of these global initiatives, WHO launched the third WHO Global Patient Safety Challenge: Medication Without Harm in 2017 [15]. This seeks to facilitate a range of strategic initiatives with the aim of improving medication safety globally. Research is fundamental to these global, regional and national efforts. To inform these deliberations, we sought to define research priorities for medication safety using an inclusive, systematic and replicable process.

\section{METHODS}

\section{Origins}

We established a management team to identify global research priorities for medication safety. After reviewing available approaches for research prioritisation, we decided to employ the Child Health and Nutrition Research Initiative (CHNRI) method [16]. This research priority setting technique was introduced in 2007 and has now successfully been applied in over 100 different exercises, a number of which have also been led by WHO [17] (see Box 1). Revised guidelines for application of the method, based on the experience of its use, have recently been published [18-23]. This followed extensive deliberation on what was learnt from working with funders, researchers and other stakeholders over the last decade, as well as the development of a revised conceptual framework and validation of the key concepts that CHNRI relies on. In June 2017, we developed a protocol to guide the process for setting priorities in medication and patient safety research globally. A small management team (including the authors of this report) coordinated the steps of the WHO priority setting exercise.

\section{Expert input}

We identified 598 experts in medication safety from across the world. We did so by searching the Web of Science's Core Collection for the most productive authors in the preceding five-year period, or those who

Box 1. The CHNRI method for setting research priorities

The CHNRI method uses the principle of crowdsourcing to score ideas against a pre-defined set of criteria. This enables funders and policymakers to view the strengths, the weaknesses, and relative ranking of each proposed research idea, based on submitted opinions of a larger number of experts. This method uses a systematic, transparent, and democratic approach to priority setting. While it allows researchers to independently generate and score research questions, it also involves funders, policymakers, and other stakeholders at an early stage of the process, ensuring their ownership of the outcomes. The CHNRI method has thus far been implemented in about 100 studies led by multilateral organisations (eg, WHO, United Nations International Children's Emergency Fund (UNICEF)), national governments (eg, India, South Africa), and funders (eg, The Bill and Melinda Gates Foundation) to set research priorities in areas ranging from the reduction of global child mortality, dementia, or disability to the efficient execution of national health plans (eg, in China). The recognised advantages of this method include its systematic nature, transparency and replicability, clearly defined context and criteria, involvement of the funders, stakeholders and policy makers, a structured way of obtaining information, informative and intuitive quantitative outputs, studying the level of agreement over each proposed research idea, and independent scoring of many experts, thus limiting the influence of individuals on the rest of the group [18-24] 
were lead authors of the top $1 \%$ most cited research articles. The key words used to identify the experts were "medication safety" and "patient safety". After removing duplicate names, we invited the resulting 457 researchers to participate. Each expert was invited to generate up to three research ideas and then systematically rank these using pre-agreed criteria (detailed below). We in addition approached 190 persons who expressed interest in medication safety through the WHO's Global Patient Safety Network. A total of 131 invitees agreed to participate and submitted their research ideas.

The management team then scrutinised the submitted ideas and ensured that the wording of each idea fitted the format for the scoring process. This led to a consolidated list of 333 unique research ideas, which were then thematically organised into 33 broader categories, each containing between three and 30 research ideas.

The larger participating scorer group, comprising 42 experts, scrutinised the list of questions and agreed on the context and the criteria for scoring. The context was defined as "global." This meant that some proposed research ideas were scored differently because they were not feasible in specific settings. We asked the scorers to state whether the context they considered for the scoring process was for high-resource or low-resource settings. The resulting data were used for sub-analyses (see later).

\section{Criteria}

The timeframe within which the results were expected from proposed research was 5-10 years. Six independent criteria were agreed and used to discriminate between the many proposed research questions identified:

(i) Answerability: Is this research question likely to be answered using the proposed methods and approaches?

(ii) Effectiveness: Is this research question likely to lead to interventions that will effectively reduce the burden of medication-related harm?

(iii) Innovativeness: Is this research question truly novel, making good use of overall technological and scientific progress?

(iv) Implementation: Is this research question likely to lead to interventions or solutions that could be readily implemented?

(v) Burden reduction: Is this research question likely to lead to a significant reduction in medication-related harm?

(vi) Equity: Is this research question likely to reduce inequity in the population?

All invited contributors were asked to score each submitted research question using these pre-defined criteria.

\section{Scoring}

Experts were offered four response options for scoring: 0 (unlikely to meet the criterion); 0.5 (not sure if it can meet the criterion); 1 (likely to meet the criterion); or left blank if the expert felt insufficiently informed to make a judgment. The scores for each criterion ranged from 0-100\%, and the overall research priority score (RPS) assigned to each research question was a simple mean of all six criteria-specific scores. Average expert agreement (AEA), defined as the level of agreement among scorers, was also calculated for each research question, as the frequency of the mode (ie, the most common score divided by the total number of scores).

\section{RESULTS}

We received scores for the 333 proposed research ideas from 42 experts (see Table S1 in Online Supplementary Document). Most experts $(n=27)$ scored with a high-resource setting in mind. Five experts did not indicate which setting they had in mind while scoring. We present the scores from the overall pool of 42 experts in Table 1 and Table S2 in Online Supplementary Document, and the results by resource context in Table 2 and Table S3 in Online Supplementary Document (high-resource context), and in Table 3 and Table S4 in Online Supplementary Document (low-resource context). Table 4 shows the 10 research questions with the most divergent scores based on the measure of AEA, which has a maximum theoretical range of $25 \%-100 \%$. Table 5 shows the lowest ranked research priorities. 
Table 1. The top 20 research priorities among the 333 proposed research questions based on the scores from 42 experts in medication safety*

\begin{tabular}{|c|c|c|c|c|c|c|c|c|c|}
\hline BANK & RESEARCH QUESTION & $\begin{array}{l}\text { AMSWER- } \\
\text { ABLE }\end{array}$ & $\begin{array}{l}\text { EFFEC- } \\
\text { TIVE }\end{array}$ & $\begin{array}{l}\text { INNO: } \\
\text { VATIVE }\end{array}$ & $\begin{array}{l}\text { IMPLE- } \\
\text { MENTABLE }\end{array}$ & $\begin{array}{l}\text { BURDEN } \\
\text { REDUCED }\end{array}$ & $\begin{array}{l}\text { EQUV:- } \\
\text { TABLE }\end{array}$ & RPS & AEA \\
\hline 1 & $\begin{array}{l}\text { To assess how the incidence of harm due to prescribing errors } \\
\text { can be reduced by different interventions in low- and mid- } \\
\text { dle-income countries. }\end{array}$ & 94 & 95 & 74 & 84 & 97 & 91 & 89.2 & 0.643 \\
\hline 2 & $\begin{array}{l}\text { To assess the prevalence, main factors responsible and the ef- } \\
\text { fective interventions for preventing severe avoidable medica- } \\
\text { tion-related patient harm in resource-limited settings through } \\
\text { pilot studies. }\end{array}$ & 90 & 92 & 76 & 85 & 90 & 88 & 86.8 & 0.575 \\
\hline 3 & $\begin{array}{l}\text { To identify affordable and effective methods of improving med- } \\
\text { ication literacy among patients in resource limited settings }\end{array}$ & 91 & 91 & 73 & 89 & 87 & 89 & 86.7 & 0.615 \\
\hline 4 & $\begin{array}{l}\text { To develop a predictive algorithm to identify individuals who } \\
\text { are at risk of serious medication-related harm. }\end{array}$ & 88 & 91 & 90 & 79 & 94 & 76 & 86.2 & 0.742 \\
\hline 5 & $\begin{array}{l}\text { To investigate the role of health communication strategies to } \\
\text { support patients with limited language proficiency, health lit- } \\
\text { eracy and education in taking medications safely. }\end{array}$ & 89 & 88 & 73 & 85 & 85 & 95 & 85.8 & 0.571 \\
\hline 6 & $\begin{array}{l}\text { To assess the impact of increasing the amount of trained hu- } \\
\text { man resources to reduce medication errors in low- and mid- } \\
\text { dle-income countries }\end{array}$ & 91 & 87 & 79 & 80 & 90 & 81 & 84.6 & 0.599 \\
\hline 7 & $\begin{array}{l}\text { To develop and validate a complexity score (c-score) to iden- } \\
\text { tify the patients who are at risk of readmission in } 30 \mathrm{~d} \text { due to } \\
\text { medication errors which could be used by pharmacists and } \\
\text { physicians }\end{array}$ & 91 & 85 & 79 & 90 & 88 & 72 & 84.3 & 0.631 \\
\hline 8 & $\begin{array}{l}\text { To improve medication safety for in-patients, through the ap- } \\
\text { plication of ergonomics and human factors in the organization } \\
\text { of the medications flow: order, distribution, stocking, prepara- } \\
\text { tion and administration. }\end{array}$ & 92 & 86 & 76 & 86 & 89 & 75 & 83.9 & 0.575 \\
\hline
\end{tabular}

To identify the most effective empowerment methods and tools for patients and their caregivers to speak up when they see the

9 potential for medication-related harm, especially applicable to patients in LMICs, as often the most impacted individuals are poorer and less educated.

To develop and validate a complexity score (c-score) for pa-

10 tients in need for de-prescribing which would help the physicians or pharmacists identify the high-risk patients who migh develop drug-drug interactions.

To identify and develop globally applicable pictograms for se-

11 lected high-risk medications which would convey the critically important safety information

To conduct a study investigating the types of medication-related

12 harm that occur in transitions between hospitals and primary care settings in LMIC.

To create patient knowledge-building tools for medication safety with critical thinking to ensure they are usable for people with low level of literacy, in a reliable format and addressing the role of internet as an information source.

To investigate how technologies could be appropriately imple-

14 mented and scaled in LMICs to better ensure that drugs are not spoiled, diverted, counterfeited, and that supply chain performance is optimized to avoid stock outs and drug shortages.

To compare the benefits of pictorial information in medication

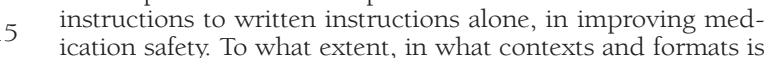
pictorial information most beneficial?

To identify what national strategies and/or policies for medication safety across high-, middle-, and low-income countries exist. What gaps remain in identifying and implementing these prevention strategies/policies?

$\begin{array}{lllllll}85 & 79 & 84 & 79 & 82 & 94 & 83.6\end{array}$

0.595

$\begin{array}{lllllllll}91 & 84 & 80 & 86 & 84 & 75 & 83.3 & 0.563\end{array}$

$\begin{array}{llllllll}87 & 82 & 72 & 83 & 88 & 87 & 83.1 & 0.536 \\ 97 & 86 & 63 & 83 & 89 & 80 & 82.8 & 0.571\end{array}$

$\begin{array}{lllllllll}88 & 83 & 80 & 81 & 78 & 86 & 82.6 & 0.623\end{array}$

$\begin{array}{llllllll}83 & 90 & 70 & 83 & 84 & 82 & 82.0 & 0.452\end{array}$

$\begin{array}{llllllll}88 & 78 & 80 & 80 & 76 & 83 & 81.0 & 0.500\end{array}$

To evaluate the impact of medication reconciliation in prevent-

17 ing medication errors in low-income countries.

To identify indicators of medication safety that have been utilised in low-resource settings. What is known about their va-

18 lidity, reliability, and feasibility, and what potential indicators should be introduced?

To investigate how to ensure patient safety for patients utiliz-

19 ing oral home-based chemotherapy administration: maximising patient education and monitoring systems.

20 To identify the reliable easily measured indicators to assess

To identify the reliable easily measured indicators to assess
medication safety both at a facility level and at national level

\begin{tabular}{lccccccc}
95 & 84 & 63 & 75 & 82 & 85 & 80.8 & 0.540 \\
94 & 85 & 63 & 73 & 85 & 83 & 80.6 & 0.563 \\
\hline 93 & 80 & 69 & 83 & 78 & 80 & 80.6 & 0.508 \\
91 & 85 & 76 & 86 & 77 & 69 & 80.6 & 0.548 \\
\hline 88 & 83 & 67 & 86 & 80 & 73 & 79.6 & 0.540 \\
\hline
\end{tabular}

RPS - research priority score, AEA - average expert agreement

* Specific scores, ranging from 0-100, are presented for each of the 6 priority-setting criteria: answerability, effectiveness, innovativeness, implementability, potential for burden reduction and equitability. Questions are ranked according to their overall research priority scores (RPS), which also has a maximum theoretical range of $0 \%-100 \%$. Average expert agreement, which can theoretically range from $25 \%-100 \%$, is also provided for each question. 
Table 2. Top 10 research priorities among the 333 proposed research questions based on the scores from 27 experts in medication safety who were scoring mainly with a high-resource context in mind, and who represent a subset of the 42 scorers*

\begin{tabular}{|c|c|c|c|c|c|c|c|c|c|}
\hline RANK & RESEARCH QUESTION & $\begin{array}{l}\text { ANSWER- } \\
\text { ABLE }\end{array}$ & $\begin{array}{l}\text { EFFEC- } \\
\text { TIVE }\end{array}$ & $\begin{array}{l}\text { INNO- } \\
\text { VATIVE }\end{array}$ & $\begin{array}{l}\text { IMPLE- } \\
\text { MENTABLE }\end{array}$ & $\begin{array}{l}\text { BURDEN } \\
\text { REDUCED }\end{array}$ & $\begin{array}{l}\text { EQUI- } \\
\text { TABLE }\end{array}$ & RPS & AEA \\
\hline 1 & $\begin{array}{l}\text { To compare the benefits of pictorial information in medication } \\
\text { instructions to written instructions alone, in improving med- } \\
\text { ication safety. To what extent, in what contexts and formats is } \\
\text { pictorial information most beneficial? }\end{array}$ & 97 & 84 & 91 & 87 & 81 & 95 & 89.1 & 0.580 \\
\hline 2 & $\begin{array}{l}\text { To identify and develop globally applicable pictograms for se- } \\
\text { lected high-risk medications which would convey the critically } \\
\text { important safety information }\end{array}$ & 93 & 88 & 80 & 89 & 94 & 90 & 89.0 & 0.599 \\
\hline 3 & $\begin{array}{l}\text { To investigate how technologies could be appropriately imple- } \\
\text { mented and scaled in LMICs to better ensure that drugs are not } \\
\text { spoiled, diverted, counterfeited, and that supply chain perfor- } \\
\text { mance is optimized to avoid stock outs and drug shortages. }\end{array}$ & 91 & 100 & 77 & 88 & 90 & 87 & 88.7 & 0.500 \\
\hline 4 & $\begin{array}{l}\text { To assess how the incidence of harm due to prescribing errors } \\
\text { can be reduced by different interventions in low- and middle-in- } \\
\text { come countries. }\end{array}$ & 95 & 97 & 71 & 75 & 100 & 87 & 87.4 & 0.568 \\
\hline 5 & $\begin{array}{l}\text { To investigate the role of health communication strategies to } \\
\text { support patients with limited language proficiency, health liter- } \\
\text { acy and education in taking medications safely. }\end{array}$ & 90 & 86 & 71 & 85 & 83 & 100 & 85.9 & 0.599 \\
\hline 6 & $\begin{array}{l}\text { To develop a predictive algorithm to identify individuals who } \\
\text { are at risk of serious medication-related harm. }\end{array}$ & 82 & 92 & 86 & 74 & 96 & 78 & 84.7 & 0.722 \\
\hline 7 & $\begin{array}{l}\text { To identify affordable and effective methods of improving medi- } \\
\text { cation literacy among patients in resource limited settings }\end{array}$ & 89 & 84 & 79 & 87 & 83 & 84 & 84.6 & 0.549 \\
\hline 8 & $\begin{array}{l}\text { To identify and create recommendations for the most effective } \\
\text { approach to decision support alerts in electronic prescribing } \\
\text { systems, the optimum sensitivity and specificity and criteria } \\
\text { which should be used to enable prescriber to receive alerts but } \\
\text { not receive alert fatigue. }\end{array}$ & 96 & 89 & 74 & 91 & 89 & 68 & 84.6 & 0.667 \\
\hline 9 & $\begin{array}{l}\text { To create patient knowledge-building tools for medication safety } \\
\text { with critical thinking to ensure they are usable for people with } \\
\text { low level of literacy, in a reliable format and addressing the role } \\
\text { of internet as an information source. }\end{array}$ & 89 & 82 & 77 & 80 & 79 & 96 & 83.7 & 0.617 \\
\hline 10 & $\begin{array}{l}\text { To develop and validate a complexity score (c-score) for patients } \\
\text { in need for de-prescribing which would help the physicians or } \\
\text { pharmacists identify the high-risk patients who might develop } \\
\text { drug-drug interactions. }\end{array}$ & 93 & 81 & 76 & 88 & 86 & 79 & 83.7 & 0.580 \\
\hline
\end{tabular}

RPS - research priority score, AEA - average expert agreement

* Specific scores, ranging from 0-100, are presented for each of the 6 priority-setting criteria: answerability, effectiveness, innovativeness, implementability, potential for burden reduction and equitability. Questions are ranked according to their overall research priority scores (RPS), which also has a maximum theoretical range of 0\%-100\%. Average expert agreement, which can theoretically range from $25 \%-100 \%$, is also provided for each question.

The overall three highest-ranking research questions (with RPS 86.7-89.2) focused on:

- Assessing how the incidence of harm due to prescribing errors can be reduced by different interventions in low-resource settings;

- Assessing the prevalence, main factors responsible and effective interventions for preventing severe avoidable medication-related patient harm in low-resource settings through pilot studies;

- Identifying affordable and effective methods of improving medication literacy among patients in resource-limited settings.

Figure 1 illustrates the key priorities for low- and high-resource settings.

Below, we consider the emerging themes, areas of overlap of priority areas, and discrepancies in more detail.

\section{Recognised importance of low-resource settings}

Our analysis shows that almost half (9 out of 20,45\%) of the top research priorities across experts related to identifying and addressing medication-related harm in low-resource settings (see Table 1). The prioritised questions included identifying existing incidence and prevalence of harm, training staff, identifying potential interventions (patient education/involvement, technology, effective medication reconciliation), and developing indicators. Three of the top 10 (30\%) priorities identified by experts working in high-resource settings concerned tackling issues in low-resource settings (see Table 2). 


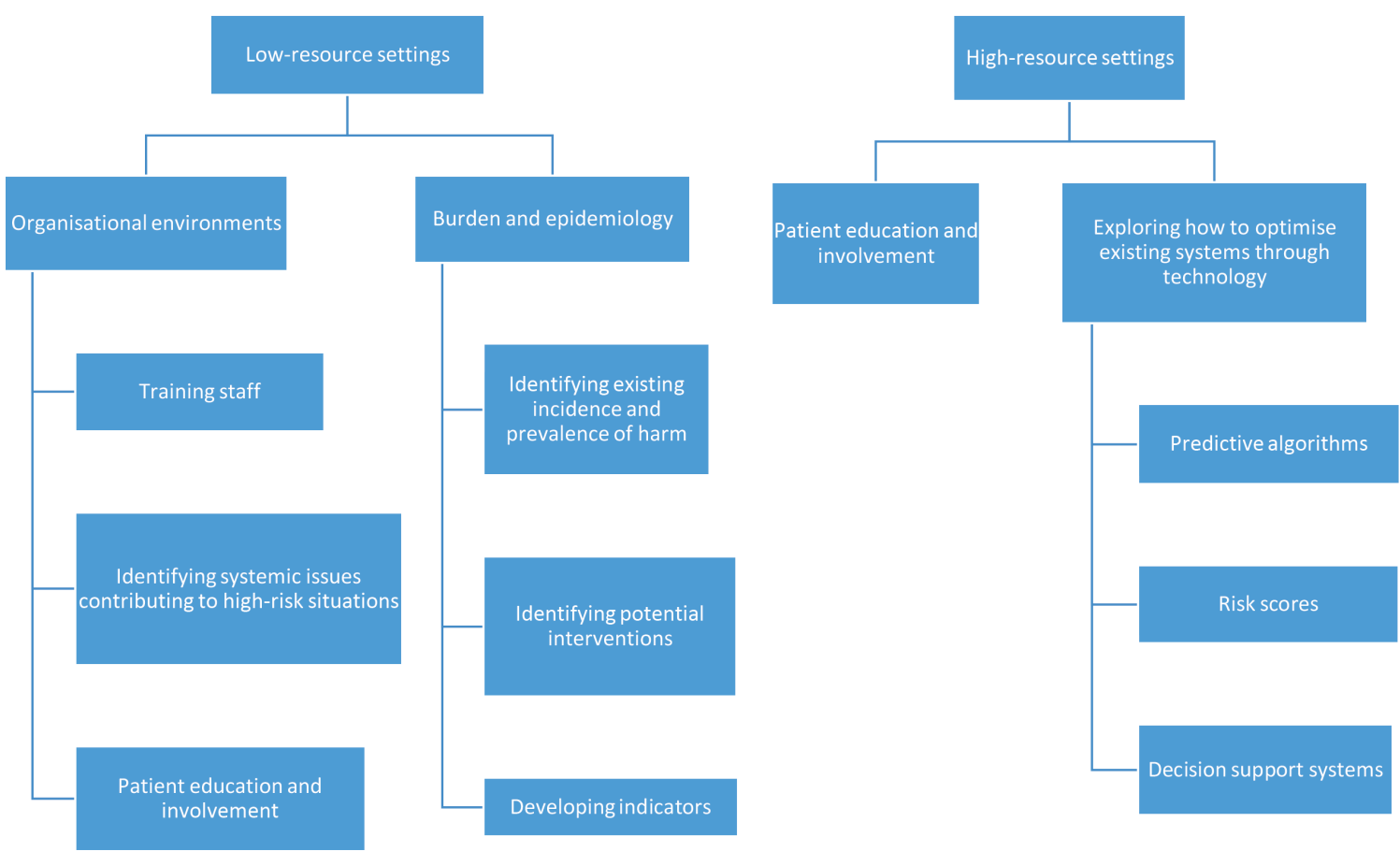

Figure 1. Key priorities for low- and high-resource settings.

\section{Exploring how to optimise existing systems through technology}

Investigating how technology can be used to optimise existing efforts aimed at reducing medication-related harm was identified as a priority, particularly in high-resource settings (Table 2). The top 20 overall priorities comprised the development of predictive algorithms and risk scores (see Table 1), and included human factors considerations, and information presentation. Of the top 10 priorities identified in high-resource settings (Table 2), four (40\%) included technology (predictive algorithms and risk scores), technology in low-resource settings, and decision support systems. Pictorial information presentation featured in $20 \%$ of identified priorities, but it is unclear if these related to digital systems. Top priorities in low-resource settings did not include technology (Table 3).

\section{Focus on organisational environments, learning and people}

Patient education and involvement was mentioned in 25\% (5 out of 20) top overall research priorities (Table 1). National strategies and policies were also mentioned, but only in $5 \%$ of overall research priorities (Table 1).

$30 \%$ of the highest ranking priorities in high-resource settings tackled patient education and involvement, but wider organisational and health system issues did not feature in the top 10 (Table 2).

Priorities in low-resource settings focused on wider questions around organisational environments in which issues surrounding medication safety are situated at a facility, system and national level (Table 3). Here, the top 10 research questions tackled exploring differences between settings with varying levels of income (30\%), identifying systemic issues contributing to high-risk situations (20\%), and promoting patient education and involvement (20\%).

\section{Overlap between lowest priority and most divergent perspectives}

The research questions with the most divergent scores centred on research topics in specific settings eg, investigating health care-associated infections, antibiotics, generic medicines, over-the-counter (OTC) medicines (Table 4). Lowest-ranked research questions focused on single study designs in specific settings and medicines, but also included procedural issues such as identifying high-risk patients (see Table 5). 
Table 3. Top 10 research priorities among the 333 proposed research questions based on the scores from 10 experts in medication safety who were scoring mainly with a low-resource context in mind, and who represent a subset of the 42 scorers*

\begin{tabular}{|c|c|c|c|c|c|c|c|c|c|}
\hline RANK & RESEARCH QUESTION & $\begin{array}{l}\text { ANSWER- } \\
\text { ABLE }\end{array}$ & $\begin{array}{l}\text { EFFEC- } \\
\text { TIVE }\end{array}$ & $\begin{array}{l}\text { INNO- } \\
\text { VATIVE }\end{array}$ & $\begin{array}{c}\text { IMPLE- } \\
\text { MENTABLE }\end{array}$ & $\begin{array}{l}\text { BURDEN } \\
\text { REDUCED }\end{array}$ & $\begin{array}{l}\text { EQUI- } \\
\text { TABLE }\end{array}$ & RPS & AEA \\
\hline 1 & $\begin{array}{l}\text { To assess and identify the weak links in the medication safety } \\
\text { process chain to consolidate the local systems and resolve the } \\
\text { occurring difficulties and differences in practice. }\end{array}$ & 88 & 100 & 94 & 94 & 94 & 100 & 94.8 & 0.733 \\
\hline 2 & $\begin{array}{l}\text { To assess the prevalence, main factors responsible and the ef- } \\
\text { fective interventions for preventing severe avoidable medica- } \\
\text { tion-related patient harm in resource-limited settings through } \\
\text { pilot studies. }\end{array}$ & 94 & 94 & 100 & 89 & 94 & 94 & 94.3 & 0.750 \\
\hline 3 & $\begin{array}{l}\text { To investigate the impact of addressing high alert medications } \\
\text { on morbidity and mortality in two pilot sites, one in LMIC } \\
\text { and one HIC. }\end{array}$ & 100 & 100 & 88 & 94 & 89 & 89 & 93.3 & 0.800 \\
\hline 4 & $\begin{array}{l}\text { To identify what national strategies and/or policies for medi- } \\
\text { cation safety across high-, middle-, and low-income countries } \\
\text { exist. What gaps remain in identifying and implementing these } \\
\text { prevention strategies/policies? }\end{array}$ & 94 & 100 & 75 & 94 & 100 & 94 & 92.7 & 0.717 \\
\hline 5 & $\begin{array}{l}\text { To identify the most effective empowerment methods and tools } \\
\text { for patients and their caregivers to speak up when they see the } \\
\text { potential for medication-related harm, especially applicable to } \\
\text { patients in LMICs, as often the most impacted individuals are } \\
\text { poorer and less educated. }\end{array}$ & 89 & 90 & 90 & 95 & 94 & 95 & 92.2 & 0.833 \\
\hline 6 & $\begin{array}{l}\text { What are the most frequent causes of severe, avoidable medi- } \\
\text { cation-related harm in high-, middle-, and low-income coun- } \\
\text { tries? If this is not known, what steps need to be taken to } \\
\text { build and/or strengthen surveillance systems to identify med- } \\
\text { ication-related harm? }\end{array}$ & 94 & 100 & 75 & 94 & 94 & 94 & 92.0 & 0.750 \\
\hline 7 & $\begin{array}{l}\text { To identify and create new indicators and metrics for medi- } \\
\text { cation safety to measure better the impact of medication safe- } \\
\text { ty work. }\end{array}$ & 93 & 93 & 93 & 93 & 93 & 86 & 91.7 & 0.583 \\
\hline 8 & $\begin{array}{l}\text { To assess the reporting and learning of medication error sys- } \\
\text { tems at global and regional level and their impact on system } \\
\text { change }\end{array}$ & 94 & 89 & 81 & 94 & 89 & 100 & 91.2 & 0.750 \\
\hline 9 & $\begin{array}{l}\text { To evaluate the prevalence of unnecessary medications and } \\
\text { food supplements, drug-drug interactions and drug-disease } \\
\text { interactions among patients who take multiple medications. }\end{array}$ & 94 & 100 & 69 & 94 & 94 & 94 & 91.1 & 0.767 \\
\hline 10 & $\begin{array}{l}\text { To investigate the correlations between patient education and } \\
\text { engagement with adherence to medication, inappropriate pre- } \\
\text { scriptions and adverse drug events; and to identify which ed- } \\
\text { ucation tools are effective and sustainable. }\end{array}$ & 94 & 95 & 80 & 100 & 95 & 80 & 90.7 & 0.850 \\
\hline
\end{tabular}

RPS - research priority score, AEA - average expert agreement

*Specific scores, ranging from 0-100, are presented for each of the 6 priority-setting criteria: answerability, effectiveness, innovativeness, implementability, potential for burden reduction and equitability. Questions are ranked according to their overall research priority scores (RPS), which also has a maximum theoretical range of $0 \%-100 \%$. Average expert agreement, which can theoretically range from $25 \%-100 \%$, is also provided for each question.

There was substantial overlap between six research priorities that were included in both the 10 research questions (60\%) with the most divergent scores and the 20 lowest priority research questions (30\%).

\section{DISCUSSION}

Our priority setting exercise has shown that medication safety is a truly global problem. Medicines are inadvertently killing and harming patients on a scale that is unacceptable. When viewed globally, and not from the perspective of some leading health care providers in high-resource countries, there has been relatively little improvement since the subject was first documented. This means that neither research, nor its translation into practice, has played a part in protecting patients. Taking a fundamental look at research priorities in medication safety is a necessary step to create opportunities to transform this situation.

There was clear recognition by the experts who participated in our study of the need for research commissioners and funders to support ideas in scope to serve most of the world's population, but also those that are innovative and with realistic prospects for implementation. At the opposite end of the priority spectrum were ideas either formulated too specifically or too focused on a specific context, or simply not clear enough. The significant overlap between the most controversial and the lowest priority areas suggests that the notion of lowest priority is somewhat contested. 
Table 4. The 10 most controversial research questions among the 333 proposed research questions based on the measure of average expert agreement, which has a maximum theoretical range of $25 \%-100 \%$ *

\begin{tabular}{|c|c|c|c|c|c|c|c|c|c|}
\hline $\begin{array}{l}\text { RANK } \\
\text { ALL }\end{array}$ & RESEARCH QUESTION & $\begin{array}{l}\text { ANSWER- } \\
\text { ABLE }\end{array}$ & $\begin{array}{l}\text { EFFEC- } \\
\text { TIVE }\end{array}$ & $\begin{array}{l}\text { INNO- } \\
\text { VATIVE }\end{array}$ & $\begin{array}{l}\text { IMPLE- } \\
\text { MENTABLE }\end{array}$ & $\begin{array}{l}\text { BURDEN } \\
\text { REDUCED }\end{array}$ & $\begin{array}{l}\text { EQUI- } \\
\text { TABLE }\end{array}$ & RPS & AEA \\
\hline 321 & $\begin{array}{l}\text { To compare generic marking of every individual medication } \\
\text { and dosage against existing medication in improving medica- } \\
\text { tion safety? }\end{array}$ & 60 & 48 & 45 & 45 & 40 & 43 & 46.9 & 0.230 \\
\hline 287 & $\begin{array}{l}\text { To conduct research into the development of expert systems en- } \\
\text { compassing a wide scope of patient information (including age, } \\
\text { gender, genetic makeup, laboratory tests), to aid as a clinical de- } \\
\text { cision support. }\end{array}$ & 54 & 56 & 54 & 54 & 61 & 54 & 55.2 & $\begin{array}{c}0 . \\
278\end{array}$ \\
\hline 314 & $\begin{array}{l}\text { To perform an observational study to identify which laboratory } \\
\text { tests can early diagnose a medication error. }\end{array}$ & 48 & 46 & 58 & 44 & 46 & 54 & 49.5 & 0.282 \\
\hline 242 & $\begin{array}{l}\text { To develop and validate models focused on aspects of hospital } \\
\text { layout and health care worker/patient flow to reduce HAIs }\end{array}$ & 73 & 54 & 55 & 66 & 64 & 52 & 60.6 & 0.282 \\
\hline 317 & $\begin{array}{l}\text { To evaluate the efficacy of generic antibiotics compared to their } \\
\text { original patented brand. Do they have the same impact on anti- } \\
\text { biotic-resistant bacteria in the digestive flora? }\end{array}$ & 64 & 44 & 44 & 46 & 46 & 46 & 48.5 & 0.282 \\
\hline 300 & $\begin{array}{l}\text { To determine factors that drive spread of HAIs and investigate } \\
\text { new approaches that minimize the role of the health care envi- } \\
\text { ronment in the spread of germs }\end{array}$ & 68 & 58 & 39 & 56 & 50 & 44 & 52.5 & 0.282 \\
\hline 331 & $\begin{array}{l}\text { To conduct an exploratory study on the conditions and regula- } \\
\text { tions needed to adopt the prescription to OTC switch. }\end{array}$ & 52 & 32 & 38 & 43 & 27 & 43 & 39.4 & 0.282 \\
\hline 322 & $\begin{array}{l}\text { To conduct a study exploring implementation methods of drug } \\
\text { classification systems in LMIC. }\end{array}$ & 58 & 40 & 39 & 52 & 42 & 46 & 46.1 & 0.290 \\
\hline 319 & $\begin{array}{l}\text { To assess the consequences to the individual's well-being and to } \\
\text { their effectiveness when the workplace pursues complete elimi- } \\
\text { nation of avoidable harm. }\end{array}$ & 50 & 50 & 52 & 46 & 48 & 39 & 47.6 & 0.290 \\
\hline 210 & $\begin{array}{l}\text { To conduct a study investigating the impact of procurement } \\
\text { based on clinical efficacy and safety, with the use of longitudinal } \\
\text { data analytics thereby optimising benefits and minimising harm. }\end{array}$ & 66 & 69 & 64 & 62 & 65 & 54 & 63.2 & 0.294 \\
\hline
\end{tabular}

RPS - research priority score, AEA - average expert agreement

*The scores from 42 experts in medication safety contributed to this ranking. Overall ranks and scores (RPS) are also provided for each question.

The scorers also were of the view that research must encompass low-resource settings, where the burden of medication-related harm is likely to be highest. Patient education and involvement were judged as priority areas across all care contexts. Priorities in high-resource settings focused on optimising existing systems through technology, whilst in low-resource settings priorities reflected the need for wider organisational changes.

The method we used to prioritise research needs is based on a systematic, well-documented process that is transparent and replicable. It is based on a collective opinion of experts. This eliminates the risk of individual scorers unduly influencing the overall score. We engaged many scorers (42 international experts), so there is a very high degree of confidence ( $>95 \%)$ that the ranking of priorities would not greatly change with a different group of scorers, unless major self-selection bias was present [23]. Differences in the contexts used to score are unlikely to have affected the scoring of most proposed research questions. They could however have had an important effect on proposed ideas that were considered not feasible in low-resource settings. This exercise also efficiently discriminated between a very large number of research questions, with RPS spread over a very wide range (27.4-89.2, see Table S2 in Online Supplementary Document).

In comparison to previously conducted CHNRI exercises, this work was characterised by a rather low response rate at all stages of scoring. The initial response rate in a typical CHNRI exercise is around $60 \%$, while the response rate at the second stage tends to be around 50\% [16]. The scoring of this study was, compared to other CHNRI exercises, burdensome for scorers, so it is possible that this may have turned away many of the invited scorers. That said, simulations have shown that a sample size of 42 scorers should still result in stable and replicable scores and rankings $[22,23]$. To support this, research questions that were similar in nature were ranked very closely together on the final list, which is one of the useful indicators of robustness of the CHNRI process.

Another limitation relates to the search strategy and sample characteristics of experts. The search strategy for experts may not be representative as the first-author, with the exception of major trials, is seldom the 
Table 5. The 20 lowest-ranked research questions among the 333 proposed research questions based on the scores from 42 experts in medication safety*

\begin{tabular}{|c|c|c|c|c|c|c|c|c|c|}
\hline RANK ALL & RESEARCH QUESTION & $\begin{array}{l}\text { ANSWER- } \\
\text { ABLE }\end{array}$ & $\begin{array}{l}\text { EFFEC- } \\
\text { TIVE }\end{array}$ & $\begin{array}{l}\text { INNOVA- } \\
\text { TIVE }\end{array}$ & $\begin{array}{l}\text { IMPLE- } \\
\text { MENTABLE }\end{array}$ & $\begin{array}{l}\text { BURDEN } \\
\text { REDUCED }\end{array}$ & $\begin{array}{l}\text { EQUI- } \\
\text { TABLE }\end{array}$ & RPS & AEA \\
\hline 314 & $\begin{array}{l}\text { To perform an observational study to identify which } \\
\text { laboratory tests can early diagnose a medication er- } \\
\text { ror. }\end{array}$ & 48 & 46 & 58 & 44 & 46 & 54 & 49.5 & 0.282 \\
\hline 315 & $\begin{array}{l}\text { To analyze and identify the root cause of multidrug } \\
\text { resistance in the treatment process to create more } \\
\text { effective interventions. }\end{array}$ & 58 & 50 & 34 & 53 & 53 & 47 & 49.4 & 0.353 \\
\hline 316 & $\begin{array}{l}\text { To conduct a longitudinal observational study of } \\
\text { patient medication non-adherence on health out- } \\
\text { comes. }\end{array}$ & 72 & 50 & 34 & 51 & 43 & 43 & 49.0 & 0.452 \\
\hline 317 & $\begin{array}{l}\text { To evaluate the efficacy of generic antibiotics com- } \\
\text { pared to their original patented brand. Do they have } \\
\text { the same impact on antibiotic-resistant bacteria in } \\
\text { the digestive flora? }\end{array}$ & 64 & 44 & 44 & 46 & 46 & 46 & 48.5 & 0.282 \\
\hline 318 & $\begin{array}{l}\text { To compare the efficacy of generic medication to the } \\
\text { original index drug and all other generic forms? }\end{array}$ & 63 & 46 & 32 & 50 & 46 & 54 & 48.5 & 0.333 \\
\hline 319 & $\begin{array}{l}\text { To assess the consequences to the individual's } \\
\text { well-being and to their effectiveness when the } \\
\text { workplace pursues complete elimination of avoid- } \\
\text { able harm. }\end{array}$ & 50 & 50 & 52 & 46 & 48 & 39 & 47.6 & 0.290 \\
\hline 320 & $\begin{array}{l}\text { To develop Shared Care Guidelines for selected med- } \\
\text { icines, to promote safe continuity of care in the com- } \\
\text { munity. }\end{array}$ & 61 & 48 & 29 & 48 & 46 & 52 & 47.3 & 0.329 \\
\hline 321 & $\begin{array}{l}\text { To compare generic marking of every individual } \\
\text { medication and dosage against existing medication } \\
\text { in improving medication safety? }\end{array}$ & 60 & 48 & 45 & 45 & 40 & 43 & 46.9 & 0.230 \\
\hline 322 & $\begin{array}{l}\text { To conduct a study exploring implementation meth- } \\
\text { ods of drug classification systems in LMIC. }\end{array}$ & 58 & 40 & 39 & 52 & 42 & 46 & 46.1 & 0.290 \\
\hline 323 & $\begin{array}{l}\text { To conduct a study investigating clinical situations } \\
\text { that lie outside the guidelines, is there an increased } \\
\text { incidence of unnecessary bridging with heparin or } \\
\text { low molecular weight heparin? }\end{array}$ & 60 & 47 & 40 & 55 & 40 & 34 & 45.9 & 0.353 \\
\hline 324 & $\begin{array}{l}\text { To develop clinical guidelines for rarely used drugs } \\
\text { and perform audits on use. }\end{array}$ & 59 & 43 & 48 & 44 & 38 & 40 & 45.4 & 0.317 \\
\hline 325 & $\begin{array}{l}\text { Assessing the benefits on patient safety and efficacy } \\
\text { of marking expiration month and date on tablets. }\end{array}$ & 62 & 39 & 41 & 53 & 38 & 40 & 45.4 & 0.349 \\
\hline 326 & $\begin{array}{l}\text { To conduct an experimental study investigating the } \\
\text { differences in the length of carriage of resistant bac- } \\
\text { teria, after exposure to a single course of antibiotics. }\end{array}$ & 70 & 41 & 40 & 35 & 39 & 37 & 43.6 & 0.353 \\
\hline 327 & $\begin{array}{l}\text { To develop digital thermometers for use with medi- } \\
\text { cine fridges and freezers. }\end{array}$ & 66 & 42 & 23 & 59 & 30 & 40 & 43.2 & 0.413 \\
\hline 328 & $\begin{array}{l}\text { To identify ways to ensure that the systemic prob- } \\
\text { lems (and failings) of medication safety amongst } \\
\text { health care professionals will not conflict with the } \\
\text { current trend of increasing patient knowledge and } \\
\text { awareness. }\end{array}$ & 45 & 38 & 47 & 43 & 43 & 40 & 42.8 & 0.341 \\
\hline 329 & $\begin{array}{l}\text { To investigate the effect on patient safety if medica- } \\
\text { tion is infused through central vs peripheral veins. }\end{array}$ & 58 & 42 & 26 & 52 & 44 & 27 & 41.4 & 0.433 \\
\hline 330 & $\begin{array}{l}\text { To research into producing a medicines handbook } \\
\text { that classifies medication by disease and patient } \\
\text { group, that can be applied to different geographic } \\
\text { country contexts. }\end{array}$ & 44 & 36 & 43 & 40 & 36 & 45 & 40.6 & 0.369 \\
\hline 331 & $\begin{array}{l}\text { To conduct an exploratory study on the conditions } \\
\text { and regulations needed to adopt the prescription to } \\
\text { OTC switch. }\end{array}$ & 52 & 32 & 38 & 43 & 27 & 43 & 39.4 & 0.282 \\
\hline 332 & $\begin{array}{l}\text { To create recommendations to accurately identify a } \\
\text { patient which could be applied to different institu- } \\
\text { tional contexts. }\end{array}$ & 50 & 42 & 27 & 48 & 38 & 25 & 38.2 & 0.329 \\
\hline 333 & $\begin{array}{l}\text { To investigate the change in the status of the medi- } \\
\text { cation to create reliable processes. }\end{array}$ & 29 & 31 & 24 & 28 & 28 & 26 & 27.4 & 0.325 \\
\hline
\end{tabular}

RPS - research priority score, AEA - average expert agreement

* Specific scores, ranging from 0-100, are presented for each of the 6 priority-setting criteria: answerability, effectiveness, innovativeness, implementability, potential for burden reduction and equitability. Questions are ranked according to their overall research priority scores (RPS), which also has a maximum theoretical range of 0\%-100\%. Average expert agreement, which can theoretically range from $25 \%-100 \%$, is also provided for each question. 
most experienced author or "expert". There was also clearly an overrepresentation of participants from high-resource settings (31 out of 42), which is likely to have influenced the results in favour of concerns important to those working in these settings. There was further a potential overrepresentation of pharmacists/pharmacologists (18 out of 42), and medical doctors (11 out of 42).

Our findings provide detailed and actionable recommendations for policymakers and research funders to begin addressing the significant burden associated with medication-related harm internationally and in countries with different levels of resources (see Tables S2-S4 in Online Supplementary Document). Furthermore, the CHNRI process offers research funders and policymakers an opportunity to understand potential strengths and weaknesses of many research ideas when evaluated against pre-defined priority-setting criteria. This can lead to a multitude of follow-up actions, depending on individual preferences.

Across countries, research priorities reflected a need to identify incidence/prevalence of harm and associated interventions (particularly in low-resource settings) as a necessary first step to improve medication safety. This is aligned with the current efforts of WHO to identify the prevalence of medication errors in low-resource settings [15]. These settings have received limited attention in the literature [25]. It also reflects issues surrounding a lack of agreement on ways to define and measure medication-related harm $[26,27]$.

Prioritised interventions tackled the alignment of informational requirements of the various stakeholders involved in the medication management process (including the patient). Whilst patient involvement reflects a wider international drive towards the increasingly active role of patients in the management of their own health and illness to improve quality of care [28], patients may also be viewed as part of a wider health information infrastructure surrounding medication-related information which is created and maintained by a wide variety of stakeholders [29].

This infrastructure may include both paper-based and electronic systems, depending on context. For instance, technology-based approaches to optimising existing medication management through secondary uses of data are more immediately relevant to high-resource settings that already have basic technological infrastructures in place [30]. Conversely, identified priorities in low-resource settings show that these countries need to focus on wider organisational changes to allow the emergence of basic informational infrastructures (technology-based or otherwise). This indicates that certain pre-requisites need to be in place before optimisation through technology can be considered [31].

\section{CONCLUSIONS}

Our method has identified and agreed research priorities for improving medication safety globally and by resource setting. WHO now plans to work with global, regional and national funding bodies to commission work pursuing these research priorities and through doing so contribute to efforts to reduce the unacceptable burden of medication-related harm.

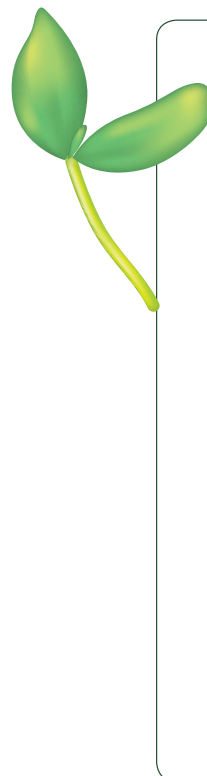

Acknowledgments: We are grateful to all the experts who contributed to this exercise.

Disclaimer: The authors alone are responsible for the views expressed in this article and they do not necessarily represent the views, decisions or policies of the institutions with which they are affiliated.

Funding: World Health Organization

Authorship contributions: AS, IR, NDK and LD conceived this paper. The CHNRI exercise was led by IR with support from MLT, MLH and KC. IR and AS led the drafting of the manuscript and all authors commented on drafts of the manuscript.

Competing interests: The authors have completed the Unified Competing Interest form at www.icmje.org/ coi_disclosure.pdf (available on request from the corresponding author).Igor Rudan is the Co-Editor in Chief of the Journal of Global Health. To ensure that any possible conflict of interest relevant to the journal has been addressed, this article was reviewed according to best practice guidelines of international editorial organisations. LJD is a member of the WHO Patient Safety Envoy and is paid travel and subsistence for WHO meetings, and for some of his advisory work. ND-K is WHO's Coordinator of Patient Safety and Risk Management. AS is a member of WHO's Third Global Patient Safety Challenge and chairs the Monitoring and Evaluation Working Group. KC, MLH and MLT declare no conflict of interests.

Additional material

Online Supplementary Document 
1 Howard RL, Avery AA. Medicines management. In: Hurwitz B, (ed.), Sheikh A, (ed.). Health Care Errors and Patient Safety. Oxford: BMJ Books Wiley-Blackwell, 2009.

2 Aitken M, Gorokhovich L. Advancing the responsible use of medicines: applying levers for change. IMS Institute for Healthcare Informatics, 2012. http://papers.ssrn.com/sol3/papers.cfm?abstract_id=2222541

3 Tam VC, Knowles SR, Cornish PL, Fine N, Marchesano R, Etchells EE. Frequency, type and clinical importance of medication history errors at admission to hospital: a systematic review. CMAJ. 2005;173:510-5. Medline:16129874 doi:10.1503/ cmaj.045311

4 Sandars J, Esmail A. The frequency and nature of medical error in primary care: understanding the diversity across studies. Fam Pract. 2003;20:231-6. Medline:12738689 doi:10.1093/fampra/cmg301

5 Gurwitz JH, Field TS, Harrold LR, Rothschild J, Debellis K, Seger AC, et al. Incidence and preventability of adverse drug events among older persons in the ambulatory setting. JAMA. 2003;289:1107-16. Medline:12622580 doi:10.1001/ jama.289.9.1107

6 Panesar SS, Carson-Stevens A, Cresswell KM, Salvilla SA, Slight SP, Javad S, et al. How safe is primary care? A systematic review. BMJ Qual Saf. 2016;25:544-53. Medline:26715764 doi:10.1136/bmjqs-2015-004178

7 Kanjanarat P, Winterstein AG, Johns TE, Hatton RC, Gonzalez-Rothi R, Segal R. Nature of preventable adverse drug events in hospitals: a literature review. Am J Health Syst Pharm. 2003;60:1750-9. Medline:14503111 doi:10.1093/ajhp/60.17.1750

8 Lazarou J, Pomeranz BH, Corey PN. Incidence of adverse drug reactions in hospitalized patients: a meta-analysis of prospective studies. JAMA. 1998;279:1200-5. Medline:9555760 doi:10.1001/jama.279.15.1200

9 Baker GR, Norton PG, Flintoft V, Blais R, Brown A, Cox J, et al. The Canadian Adverse Events Study: the incidence of adverse events among hospital patients in Canada. CMAJ. 2004;170:1678-86. Medline:15159366 doi:10.1503/cmaj.1040498

10 de Vries EN, Ramrattan MA, Smorenburg SM, Gouma DJ, Boermeester MA. The incidence and nature of in-hospital adverse events: a systematic review. Qual Saf Health Care. 2008;17:216-23. Medline:18519629 doi:10.1136/qshc.2007.023622

11 Leape LL. Error in medicine. JAMA. 1994;272:1851-7. Medline:7503827 doi:10.1001/jama.1994.03520230061039

12 Alsulami Z, Conroy S, Choonara I. Medication errors in the Middle East countries: a systematic review of the literature. Eur J Clin Pharmacol. 2013;69:995-1008. Medline:23090705 doi:10.1007/s00228-012-1435-y

13 Pittet D, Donaldson L. Clean Care is Safer Care: a worldwide priority. Lancet. 2005;366:1246-7. Medline:16214584 doi:10.1016/S0140-6736(05)67506-X

14 World Alliance for Patient Safety; World Health Organization. WHO guidelines for safe surgery: 2009: safe surgery saves lives. Geneva: World Health Organization; 2009.

15 Donaldson LJ, Kelley ET, Dhingra-Kumar N, Kieny MP, Sheikh A. Medication without harm: WHO third global patient safety challenge. Lancet. 2017;389:1680-1. Medline:28463129 doi:10.1016/S0140-6736(17)31047-4

16 Rudan I. Global health research priorities: mobilizing the developing world. Public Health. 2012;126:237-40. Medline:22325672 doi:10.1016/j.puhe.2011.12.001

17 Rudan I, Yoshida S, Chan KY, Sridhar D, Wazny K, Nair H, et al. Setting health research priorities using the CHNRI method: VII. A review of the first 50 applications of the CHNRI method. J Glob Health. 2017;7:011004. Medline:28685049 doi:10.7189/jogh.07.011004

18 Rudan I, Yoshida S, Chan KY, Cousens S, Sridhar D, Bahl R, et al. Setting health research priorities using the CHNRI method: I. Involving funders. J Glob Health. 2016;6:010301. Medline:26401269

19 Yoshida S, Cousens S, Wazny K, Chan KY. Setting health research priorities using the CHNRI method: II. Involving researchers. J Glob Health. 2016;6:010302. Medline:27350870 doi:10.7189/jogh.06.010302

20 Yoshida S, Wazny K, Cousens S, Chan KY. Setting health research priorities using the CHNRI method: III. Involving stakeholders. J Glob Health. 2016;6:010303. Medline:27303649 doi:10.7189/jogh.06.010303

21 Rudan I. Setting health research priorities using the CHNRI method: IV. Key conceptual advances. J Glob Health. 2016;6:010501. Medline:27418959 doi:10.7189/jogh.06.010501

22 Rudan I, Yoshida S, Wazny K, Chan KY, Cousens S. Setting health research priorities using the CHNRI method: V. Quantitative properties of human collective knowledge. J Glob Health. 2016;6:010502. Medline:27350873 doi:10.7189/jogh.06.010502

23 Yoshida S, Rudan I, Cousens S. Setting health research priorities using the CHNRI method: VI. Quantitative properties of human collective opinion. J Glob Health. 2016;6:010503. Medline:27350874 doi:10.7189/jogh.06.010503

24 Rudan I, Gibson JL, Ameratunga S, El Arifeen S, Bhutta ZA, Black M, et al; Child Health and Nutrition Research Initiative. Setting priorities in global child health research investments: guidelines for implementation of CHNRI method. Croat Med J. 2008;49:720-33. Medline:19090596 doi:10.3325/cmj.2008.49.720

25 IMS Institute for Healthcare Informatics. The global use of medicines: outlook through 2016. Parsipanny, NJ: IMS; 2012.

26 Lisby M, Nielsen LP, Brock B, Mainz J. How are medication errors defined? systematic literature review of definitions and characteristics. Int J Qual Health Care. 2010;22:507-18. Medline:20956285 doi:10.1093/intqhc/mzq059

27 Inch J, Watson MC, Anakwe-Umeh S. Patient versus healthcare professional spontaneous adverse drug reaction reporting: a systematic review. Drug Saf. 2012;35:807-18. Medline:22928729 doi:10.1007/BF03261977

28 Patient engagement and involvement. The King's Fund. Available from: https://www.kingsfund.org.uk/projects/gp-inquiry/ patient-engagement-involvement

29 Monteiro E, Pollock N, Williams R. Innovation in Information Infrastructures: Introduction to the Special Issue. JAIS 2014;15:I-X. doi:10.17705/1jais.00359

30 Jha AK, Doolan D, Grandt D, Scott T, Bates DW. The use of health information technology in seven nations. Int J Med Inform. 2008;77:848-54. Medline:18657471 doi:10.1016/j.ijmedinf.2008.06.007

31 Urwiler R, Frolick MN. The IT value hierarchy: Using Maslow's hierarchy of needs as a metaphor for gauging the maturity level of information technology use within competitive organizations. Inf Syst Manage. 2008;25:83-8. doi:10.1080/10580530701777206 